\title{
Screening and selection of ten potato genotypes (Solanum tuberosum L.) for their relative tolerance and susceptibility to the fumigation of the elevated $\mathrm{O}_{3}$ levels
}

\author{
V.S. SUGANTHY AND C. UDAYASOORIAN
}

Article Chronicle : Received: 01.02.2016;

Revised : 11.04.2016; Accepted :

20.04.2016

Key Words : Elevated ozone, Potato genotypes, Visual injury, Physiological parameters, Tuber yield
Author for correspondence : V.S. SUGANTHY ISRO-Climate Change Observatory,

Horticultural Research Station, (T.N.A.U.), OOTY (T.N.) INDIA

Email : suganthy95soil@ gmail.com

See end of the article for Coopted authors'
ABSTRACT : Ozone $\left(\mathrm{O}_{3}\right)$ is a phytotoxic air pollutant as well as a hidden threat to food security in South Asia and reduces the crop yield to an extent of 20 to 35 per cent. Projections of future global $\mathrm{O}_{3}$ trends show that the present mean global concentration of $50 \mathrm{ppb}$ in the ambient air will increase rapidly over the next 20 to 30 years with an annual increase of $7.2 \mathrm{ppb}$. The study on impact of three elevated $\mathrm{O}_{3}$ levels $(100,150$ and $200 \mathrm{ppb})$ during the tuber initiation stage of ten potato genotypes (Kufri Surya, Kufri Swarna, Kufri Jyothi, Kufri Chipsona, Kufri Jawahar, Kufri Giriraj, Kufri Muthu, Kufri Himsona, Kufri Giridhari and Kufri Himalini) on their growth, physiology and yield characteristics in open-top chamber showed that the potato genotype Kufri Surya recorded the highest green leaf area per cent (84.50 - 95.75), photosynthetic rate $\left(26.56-24.85 \mu \mathrm{mol} \mathrm{CO}_{2} \mathrm{~m}^{-1} \mathrm{~s}^{-1}\right)$, stomatal conductance $\left(0.625-0.595 \mathrm{~cm} \mathrm{~s}^{-1}\right)$, tuber fresh weight $\left(0.650 \mathrm{~kg} \mathrm{plant}^{-1}\right)$ and number of tubers with the lowest visual leaf injury per cent $(4.25-15.5)$ proved its moderately resistant nature to all the three elevated $\mathrm{O}_{3}$ levels. Among ten potato genotypes, Kufri Himalini showed the highest visible injury per cent (99.5) with lowest growth, physiological characteristics with no tuber formation at 150 and $200 \mathrm{ppb}$ elevated $\mathrm{O}_{3}$ levels.

HOW TO CITE THIS ARTICLE : Suganthy, V.S. and Udayasoorian, C. (2016).Screening and selection of ten potato genotypes (Solanum tuberosum L.) for their relative tolerance and susceptibility to the fumigation of the elevated $\mathrm{O}_{3}$ levels. Asian J. Environ. Sci., 11(1): 1-6, DOI: 10.15740/HAS/AJES/11.1/1-6. 